\title{
ANALISIS KINERJA KEUANGAN LEMBAGA PERKREDITAN DESA ADAT BANGKANG BAKTISERAGA MENGGUNAKAN ANALISIS DU PONT
}

\author{
Putri Anggreni \\ Fakultas Ekonomi, Universitas Mahendradatta \\ Email: gekcay@gmail.com
}

\begin{abstract}
The management is required to always introspect condition of the company, especially in terms of financialnya, because it holds the key to life and death of the company. The condition that the company should always be monitored, can be done by analyzing the financial statements themselves, which generally consist of a balance sheet and income statement. Through the analysis of the financial statements can be found successful achievement of achievement demonstrated by the absence of a healthy financial statements, which is the basis of performance appraisal or part of the existing work in the company. Used in this study to analyze the financial statements is Du Pont, aims to determine the state of Indigenous Village Credit Institutions Bangkang Baktiseraga which was done by measuring the financial performance. Analysis of Du Pont is one of the techniques that are thorough financial analysis, management can determine the level of efficiency of capital use. Financial performance results obtained from the calculation of Return on Assets and Return on Equity from year to year decline, but is still in good health as above average standard of Bank Indonesia. Village Credit Institutions should determine the condition of future performance in order to be a better performance than the previous year and the profit achieved will also be maximized.

Key words: Financial Performance, LPD, ROA, ROE, Du Pont Analysis
\end{abstract}

\begin{abstract}
ABSTRAK
Pihak manajemen dituntut untuk selalu mengintrospeksi kondisi perusahaan terutama dari segi finansialnya, karena hal tersebut memegang kunci hidup matinya perusahaan. Kondisi perusahaan yang harus selalu dipantau, dapat dilakukan dengan menganalisa laporan keuangan sendiri yang pada umumnya terdiri dari laporan neraca dan laporan laba rugi. Melalui analisis laporan keuangan dapat diketahui keberhasilan tercapainya prestasi yang ditunjukkan oleh sehat tidaknya laporan keuangan tersebut, yang merupakan dasar penilaian prestasi atau hasil kerja bagian yang ada di perusahaan. Dalam penelitian ini yang digunakan untuk menganalisa laporan keuangan tersebut adalah Du Pont, bertujuan untuk mengetahui keadaan Lembaga Perkreditan Desa Adat Bangkang Baktiseraga yang dilakukan dengan cara mengukur kinerja keuangan. Analisis Du Pont merupakan salah satu teknik analisa keuangan yang sifatnya menyeluruh, manajemen bisa mengetahui tingkat efisiensi penggunaan modal. Hasil kinerja keuangan yang diperoleh dari perhitungan Return On Asset dan Return On Equity dari tahun ke tahun mengalami penurunan, tetapi masih dalam keadaan sehat karena di atas standar rata-rata Bank Indonesia. Lembaga Perkreditan Desa sebaiknya mengetahui kondisi kinerja agar ke depannya kinerja menjadi lebih baik lagi dari tahun sebelumnya dan laba yang dicapai juga akan maksimal.
\end{abstract}

Kata kunci: Kinerja Keuangan, LPD, ROA, ROE, Analisis Du Pont 
Versi Online: http://journal.ubm.ac.id/

Hasil Penelitian

\section{PENDAHULUAN}

Era globalisasi ini dunia usaha semakin berkembang pesat, namun di sisi lain keadaan perekonomian negara Indonesia saat ini dalam keadaan yang kurang menguntungkan. Menurut Elfrindi : "ekonomi Indonesia saat ini akan lebih buruk, karena terjadinya krisis moneter yang berkepanjangan yang sampai sekarang belum bisa terselesaikan".

Hal ini membuat banyak perusahaan yang gulung tikar akibat keadaan tersebut. Fenomena di atas menjelaskan bahwa perusahaan sebagai organisasi profit oriented untuk selalu meningkatkan kuantitas serta kualitas usahanya sehingga keuntungan yang diharapkan akan tercapai. Pihak manajemen dituntut untuk mengantisipasi kondisi seperti ini dengan selalu mengintrospeksi kondisi perusahaan terutama dari segi finansialnya, karena hal tersebut memegang kunci hidup matinya perusahaan. Kondisi perusahaan yang harus selalu dipantau, dapat dilakukan dengan menganalisis laporan keuangan sendiri yang pada umumnya terdiri dari laporan neraca dan laporan laba/rugi. Melalui analisis laporan keuangan dapat diketahui keberhasilan tercapainya prestasi yang ditunjukkan oleh sehat tidaknya laporan keuangan tersebut, yang merupakan dasar penilaian prestasi atau hasil kerja bagian yang ada di perusahaan.

Tabel 1. Laporan Keuangan LPD Bangkang Baktiseraga Periode 2014-2016 (Dalam Ribuan Rupiah)

\begin{tabular}{|c|c|c|c|c|c|c|c|c|}
\hline Tahun & Laba Bersih & $\mathbf{\%}$ & $\begin{array}{c}\text { Pendapatan } \\
\text { Operasional }\end{array}$ & $\mathbf{\%}$ & $\begin{array}{c}\text { Total } \\
\text { Asset }\end{array}$ & $\mathbf{\%}$ & Ekuitas & $\%$ \\
\hline 2014 & 12.903 & - & 64.154 & - & 198.266 & - & 25.763 & - \\
\hline 2015 & 8.324 & $(55 \%)$ & 41.663 & $(54 \%)$ & 223.384 & $11 \%$ & 23.536 & $\begin{array}{c}(9,5 \% \\
)\end{array}$ \\
\hline 2016 & 9.277 & $(39 \%)$ & 47.093 & $(36 \%)$ & 211.798 & $6,4 \%$ & 26.153 & $1,5 \%$ \\
\hline
\end{tabular}

Sumber: Laporan Keuangan LPD Bangkang Baktiseraga Periode Tahun 2014-2016.

Dari Tabel 1 di atas dijelaskan bahwa laba bersih tahun 2015 mengalami penurunan 55\% dibandingkan tahun 2014, begitu juga laba bersih tahun 2016 menunjukkan penurunan $39 \%$ dari laba tahun 2014. Pendapatan operasional di tahun 2015 mengalami penurunan sebesar $54 \%$ dibandingkan tahun 2014, untuk pendapatan operasional tahun 2016 juga menurun menjadi $36 \%$ dari tahun 2014 .
Business Management Journal

Salah satu dasar yang dijadikan pertimbangan sebagai acuan dalam mengukur kinerja perusahaan adalah laporan keuangan. Lembaga Perkreditan Desa yang menjadi obyek penelitian ini merupakan lembaga keuangan yang bersifat khusus yakni lembaga keuangan milik komunitas adat Bali. Kepemilikan Lembaga keuangan ini adalah milik desa adat di Bali yang dengan sendirinya adalah milik masyarakat desa, karena keberadaannya di desa maka nasabahnya adalah masyarakat desa setempat baik sebagai debitur maupun kreditur. Sebagai lembaga milik desa adat dengan sendirinya hasil pengelolaannya akan dinikmati oleh masyarakat desa setempat.

Sebagai sumber hukum bagi kehidupan Lembaga Perkreditan Desa di Bali, memuat pengertian Lembaga Perkreditan Desa di Bali adalah Lembaga yang didirikan oleh desa adat dan berfungsi sebagai wadah kekayaan desa adat yang melaksanakan fungsi pemberdayaan ekonomi masyarakat pedesaan di Bali (Perda no 4 tahun 2012). Lembaga Perkreditan Desa untuk bisa menghimpun dana yang signifikan dari masyarakat, maka perlu alat ukur yang digunakan untuk menganalisa laporan keuangan (Warsono, 2003:24).
Total asset tahun 2015 peningkatan sebesar 11\% dari tahun 2014, dan juga tahun 2016 mengalami peningkatan sebesar 6,4\%. Ekuitas tahun 2015 mengalami penurunan sebesar 9,5\% dari tahun 2014 tetapi tahun 2016 mengalami peningkatan $1,5 \%$.

Berdasarkan latar belakang yang telah diuraikan di atas maka penulis mengadakan penelitian dengan judul "Analisis Kinerja 
Keuangan Lembaga Perkreditan Desa Adat Bangkang Baktiseraga Menggunakan Analisis Du Pont".

Lembaga Perkreditan Desa Bangkang Baktiseraga merupakan lembaga keuangan yang bersifat khusus yakni lembaga keuangan milik komunitas adat Bali yang saat ini sedang berkembang di Buleleng khususnya di Desa Pakraman Bangkang Baktiseraga.

Berdasarkan uraian di atas, maka dapat dirumuskan masalah sebagai berikut: Bagaimana kinerja keuangan Lembaga Perkreditan Desa Adat Bangkang Baktiseraga periode tahun 2014-2016 ditinjau dari analisis Du Pont?

Tujuan Penelitian adalah untuk mengetahui bagaimana kinerja keuangan Lembaga Perkreditan Desa Adat Bangkang Baktiseraga periode tahun 2014-2016 ditinjau dari analisis Du Pont.

Manfaat Penelitian agar Lembaga Perkreditan Desa dapat menggunakan hasil penelitian sebagai bahan pertimbangan atau sumbangan pemikiran dalam menentukan kebijaksanaannya guna kemajuan Lembaga Perkreditan Desa Adat Bangkang Baktiseraga.

\section{TINJAUAN PUSTAKA}

Laporan keuangan meliputi bagian dari proses laporan keuangan. Laporan keuangan yang lengkap biasanya meliputi neraca, laporan laba rugi, laporan perubahan ekuitas, laporan perubahan posisi keuangan (yang dapat disajikan dalam berbagai cara misalnya, sebagai laporan arus kas/laporan arus dana), catatan dan laporan lain serta materi penjelasan yang merupakan bagian integral dari laporan keuanga, Ikatan Akuntan Indonesia (2009:1) .

Laporan keuangan adalah merupakan pokok atau hasil akhir dari suatu proses akuntansi yang menjadi bahan informasi bagi para pemakainya sebagai salah satu bahan dalam proses pengambilan keputusan dan juga dapat menggambarkan indikator kesuksesan suatu perusahaan mencapai tujuannya, Harahap (2002:7).

Laporan keuangan merupakan laporan periodik yang disusun menurut prinsip-prinsip akuntansi yang diterima secara umum tentang status keuangan dari individu, sosiasi atau organisasi bisnis yang terdiri dari neraca, laporan laba rugi, laporan perubahan ekuitas, laporan arus kas dan catatan atas laporan keuangan dalam Standar Akuntansi Keuangan PSAK No. 1 (IAI, 2004:4).

Dari uraian pengertian di atas maka dapat disimpulkan bahwa laporan keuangan merupakan tempat dimana informasi-informasi keuangan disajikan serta merupakan proses pelaporan yang ditujukan kepada pikah-pihak yang berkepentingan sebagai dasar pengambilan suatu keputusan, yang dilaporkan dalam perhitungan neraca dan rugi-laba, serta laporan perubahan modal, dan laporan arus kas, dimana neraca menunjukkan jumlah asset, kewajiban dan modal perusahaan.

Analisis laporan keuangan adalah menguraikan pos-pos laporan keuangan menjadi unit informasi yang lebih kecil dan melihat hubungannya yang bersifat signifikan atau yang mempunyai makna antara satu dengan yang lain baik antara data kuantitatif maupun data bukan kuantitatif dengan tujuan untuk mengetahui kondisi keuangan lebih dalam yang sangat penting dalam proses menghasilkan keputusan yang tepat (Harahap, 2011:190).

Analisis laporan keuangan adalah analisis laporan keuangan yang terdiri dari penelaahan atau mempelajari daripada hubungan dan tendensi atau kecenderungan (trend) untuk menentukan posisi keuangan dan hasil operasi serta perkembangan perusahaan yang bersangkutan Munawir (2010:35).

Setyautama(2004:170), mengemukakan bahwa Analisis laporan keuangan dari sudut pandang manajemen mengaitkan semua pertanyaan yang diajukan oleh kreditur, karena pemakai laporan keuangan ini harus mengetahui kemampuan perusahaan untuk memperoleh modal yang dibutuhkan.

Analisa keuangan perusahaan merupakan kajian secara kritis, sistematis dan metodologis terhadap laporan keuangan untuk mengetahui kondisi keuangan baik pada waktu yang telah 
Versi Online: http://journal.ubm.ac.id/ Hasil Penelitian

lalu, kondisi tahun berjalan maupun prediksi waktu yang akan datang, Abdullah (2001:33).

Analisis laporan keuangan berarti menguraikan akun-akun laporan keuangan menjadi unit informasi yang lebih kecil dan melihat hubungannya yang bersifat signifikan atau yang mempunyai makna antara yang satu dengan yang lain baik antara data kuantitatif maupun data non kuantitatif dengan tujuan untuk mengetahui kondisi keuangan lebih dalam yang sangat penting dalam proses menghasilkan keputusan yang tepat, Harahap (2009:190).

Analisa laporan keuangan merupakan suatu informasi yang ditujukan untuk masyarakat, pemerintah, pemasok, dan kreditur, pemilik perusahaan atau pemegang saham, manajemen perusahaan, investor, pelanggan dan karyawan yang diperlukan secara tetap untuk mengukur kondisi dan efisiensi operasi perusahaan. Analisa dari laporan keuangan ini bersifat relatif karena didasarkan pada pengetahuan dan menggunakan rasio atau nilai relatif, Ridwan dan Inge (2003:128).

Tujuan analisis laporan keuangan adalah untuk membantu pemakai dalam memperkirakan masa depan dengan cara membandingkan, mengevaluasi, dan menganalisis kecenderungan, Rahardjo (2001:85). Analisis laporan keuangan perusahaan pada dasarnya merupakan perhitungan rasio-rasio untuk menilai keadaan keuangan perusahaan di masa lalu, saat ini, dan kemungkinannya di masa depan.

Ada dua metode analisis yang digunakan oleh setiap penganalisis laporan keuangan, yaitu analisis horisontal dan analisis vertikal. Analisis horisontal adalah analisis dengan mengadakan perbandingan laporan keuangan untuk beberapa periode atau beberapa saat sehingga akan diketahui perkembangannya. Analisis vertikal adalah apabila laporan keuangan yang dianalisis hanya meliputi satu periode atau satu saat saja, yaitu dengan memperbandingkan antara akun yang satu dengan akun yang lain dalam laporan keuangan tersebut sehingga hanya akan diketahui keadaan keuangan atau hasil operasi pada saat itu saja, Munawir (2010:36).

Menurut Rahardjo (2001:88) ada tiga teknik analisis yang sering digunakan, yaitu: (1) Analisis Horisontal yaitu perbandingan data keuangan untuk periode dua tahun atau lebih. Analisis horisontal sangat membantu karena menyajikan perubahan antar tahun baik dalam bentuk nilai rupiah maupun prosentase; (2) Analisis Vertikal yaitu laporan umum (commonzise statement), dalam analisis ini komponen-komponen dalam laporan laba rugi dan neraca dinyatakan dalam prosentase. Pada laporan laba rugi dipersentasekan ke penjualan, sedangkan pada neraca dipersentasekan ke aktiva atau pasiva. Besarnya persentase pada tahun yang dievaluasikan kemudian dibandingkan dengan tahun yang sebelumnya; (3) Analisis keuangan atau lebih dikenal sebagai analisis rasio, rasio (perbandingan) dapat dilakukan untuk antar sepasang pos baik dalam neraca maupun perhitungan laba rugi.

Du Pont adalah nama perusahaan yang mengembangkan analisis ini, sehingga disebut Analisis Du Pont. Du Pont Analisis pertama kali diperkenalkan pada tahun 1919 oleh F. Donaldson Brown, seorang eksekutif keuangan dari EI Du Pont de Nemours and Co., Wilmington, Delaware. Ketika tahun 1914 Perusahaan Du Pont membeli saham General Motors yang saat itu mengalami masalah, analisis ini memberikan kontribusi yang sangat penting. Berkat peranan CEO Du Pont saat itu, General Motors tumbuh menjadi produsen mobil terbesar di dunia dan dekomposisi $R O A$ yang digunakan menjadi populer.

Dalam perkembangannya, analisis $D u$ Pont dilakukan dengan memecahkan Return On Equity menjadi beberapa bagian. Return On Equity menggambarkan besarnya imbal hasil yang didapat oleh pemegang saham. Dengan memecahkan perhitungan ROE dapat mengetahui bagaimana suatu bisnis mendapatkan keuntungan. Analisis $\mathrm{Du}$ Pont memberitahu bahwa $R O E$ dipengaruhi oleh operasi efisiensi yang diukur dengan profit margin, asset menggunakan efisiensi yang diukur oleh perputaran total asset, dan leverage 
keuangan diukur oleh multiplier ekuitas. Analisis $D u$ Pont adalah $R O A$ yang dihasilkan melalui perkalian antara keuntungan dari komponen-komponen penjualan serta efisiensi penggunaan total asset di dalam menghasilkan keuntungan tersebut, Syamsudin (2000:64).

Yang dapat diuraikan dengan menggunakan analisis $D u$ Pont adalah ROA (Return On Assets) yang merupakan angka pembanding atau rasio antara laba yang diperoleh perusahaan dengan besarnya total asset perusahaan, Soediyono (2001:137).

Sedangkan pendapat Sutrisno (2001:256), analisis $\mathrm{Du}$ Pont adalah suatu analisis yang digunakan untuk mengontrol perubahan dalam rasio aktivitas dan net profit margin dan seberapa besar pengaruhnya terhadap $R O A$.

Menurut Keown (2004:102), "analisa $D u$ Pont adalah sistem rasio keuangan yang dirancang untuk menyelidiki determinan rasio pengembalian ekuitas pemegang saham dan pengembalian aktiva".

Du Pont sistem merupakan cara yang efektif dalam menganalisa laporan keuangan perusahaan dengan model mengerucut, dimana hasilnya akan didapatkan nilai $R O E$ dari suatu perusahaan. Analisis $D u$ Pont System ini bersifat menyeluruh karena mencakup tingkat efisiensi perusahaan dalam penggunaan aktivanya dan dapat mengukur tingkat keuntungan. Bagian-Bagian Du Pont: (1) Return On Asset (ROA) yaitu rasio antara Net Income After Tax terhadap asset secara keseluruhan menunjukan ukuran produktivitas aktiva dalam memberikan pengembalian pada penanaman modal, (Sawir, 2001); (2) Return On Equity (ROE) yang merupakan perbandingan antara laba bersih dengan ekuitas ini merupakan salah satu dari dua faktor dasar dalam menentukan pertumbuhan tingkat pendapatan perusahaan. Ada dua sisi dalam menggunakan ROE, kadang-kadang diasumsikan bahwa $R O E$ yang akan datang merupakan perkiraan dari $R O E$ yang lalu. Tetapi $R O E$ yang tinggi pada masa yang lalu tidak menjamin $R O E$ yang akan datang masih tetap tinggi Bodie, Kane and Marcus (2002).
Seorang analis keuangan memerlukan ukuran tertentu, yang paling sering digunakan adalah rasio atau indeks yang menunjukkan hubungan antara data keuangan, Husnan dan Padjiastuti (2004 : 200).

Bastian (2006:317), dalam bukunya Akuntansi Sektor Publik Di Indonesia menjelaskan bahwa, kinerja adalah gambaran tingkat pencapaian pelaksanaan suatu kegiatan atau program atau kebijaksanaan dalam mewujudkan sasaran, tujuan misi dan visi organisasi yang tertuang dalam perumusan skema strategi (strategic planning) suatu organisasi.

Menurut Mahsun (2006:145) kinerja keuangan menjelaskan bahwa: "kinerja merupakan suatu manajemen yang digunakan untuk meningkatkan kualitas pengambilan keputusan dan akuntabilitas".

Kinerja keuangan perusahaan merupakan satu diantara dasar penilaian mengenai kondisi keuangan perusahaan yang dilakukan berdasarkan analisa terhadap rasio keuangan perusahaan. Pihak yang berkepentingan sangat memerlukan hasil dari pengukuran kinerja keuangan perusahaan untuk dapat melihat kondisi perusahaan dan tingkat keberhasilan perusahaan dalam menjalankan kegiatan operasionalnya, Munawir (2010:30).

Dalam menilai kinerja keuangan yang menggunakan analisis rasio keuangan perlu diketahui standar rasio keuangan tersebut, Sawir (2003:144)

Berdasarkan konsep hipotesis di atas, maka penulis megemukakan hipotesis dalam penelitian ini adalah: (1) Jika ROA semakin menunjukkan nilai yang besar maka Lembaga Perkreditan Desa dinyatakan sehat; (2) Jika $R O E$ tinggi maka Lembaga Perkreditan Desa semakin bagus dan dinyatakan sehat.

\section{METODE PENELITIAN}

Dalam penelitian ini, variabel-variabel yang dianalisis sebagai berikut:

1. $\quad$ Analisis Du Pont

Analisis $D u$ Pont, adalah analisis yang mencakup rasio aktivitas dan margin keuntungan atas pendapatan untuk menentukan 
profitabilitas, dan suatu analisis yang digunakan untuk mengontrol perubahan dalam rasio aktivitas dan net profit margin dan seberapa besar pengaruhnya terhadap $R O A$ yang dimiliki Lembaga Perkreditan Desa Adat Bangkang Baktiseraga. Dari analisis ini juga dapat diketahui efisiensi atas penggunaan aktiva Lembaga Perkreditan Desa Adat Bangkang Baktiseraga periode tahun 20142016, yang diuraikan pada analisis $D u$ Pont adalah $R O A$ dan $R O E$.

\section{Return On Asset}

Return On Asset pada Lembaga Perkreditan Desa Adat Bangkang Baktiseraga merupakan rasio imbalan aktiva dipakai untuk mengevaluasi apakah manajemen pada Lembaga Perkreditan Desa Adat Bangkang Baktiseraga telah mendapat imbalan yang memadai (reasobable return) dari aktiva yang dikuasainya pada Adat Bangkang Baktiseraga tersebut. ROA diperoleh dengan mengalikan margin laba bersih dan perputaran total asset. Perputaran total asset diperoleh dari hasil bagi antara hasil penjualan dengan jumlah asset, sedangkan margin laba bersih merupakan hasil bagi antara laba bersih dengan hasil penjualan. Laba bersih merupakan hasil dari penjualan dikurangi beban-beban. Menurut Tata Cara Penilaian Kesehatan LPD (2012), rasio ini dapat di rumuskan sebagai berikut;

$R O A=$ Laba tahun berjalan $\times 100 \%$

Total Assets

\section{3. $\quad$ Return On Equity}

Return On Equity merupakan rasio yang digunakan untuk mengukur kemampuan manajemen Lembaga Perkreditan Desa Adat Bangkang Baktiseraga dalam mengelola capital yang ada untuk mendapatkan net income. Lembaga Perkreditan Desa Adat Bangkang Baktiseraga tersebut, untuk rasio ini berdasarkan Return

On Equity atau rentabilitas modal sendiri merupakan rasio untuk mengukur laba bersih sesudah pajak dengan modal sendiri. Rasio ini menunjukkan efisiensi penggunaan modal sendiri pada LPD Bangkang Baktiseraga periode tahun 2014-2016. Menurut Sawir (2001), rasio ini dirumuskan sebagai berikut:

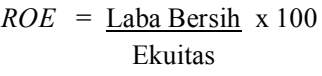

Setiap penelitian memerlukan data atau informasi dari sumber-sumber yang dapat dipercaya, agar data dan informasi tersebut digunakan untuk menjawab tujuan penelitian atau menjawab pertanyaan penelitian. Data diperoleh dari sejumlah lokasi, populasi dan sampel penelitian.

Populasi dalam penelitian ini adalah laporan keuangan neraca dan laba rugi tahun 2010 sampai dengan tahun 2016. Seluruh objek dalam populasi dijadikan sampel penelitian sehingga sampel yang digunakan pada penelitian ini adalah laporan keuangan neraca dan laba rugi tahun 2014 sampai dengan tahun 2016.

Penelitian ini menggunakan random sampling secara sistematis. Teknik sampling secara sistematis (systematic sampling), yaitu laporan neraca dan rugi laba tahun 2014-216. Dokumen, pengambilan data melalui dokumen tertulis maupun elektronik dari lembaga atau institusi.

Metode pengumpulan data yang digunakan dalam penelitian ini adalah:

Penelitian Kepustakaan

Penelitian yang dilakukan dari berbagai literatur seperti buku, jurnal, dan internet, yang berhubungan dengan aspek penelitian, untuk mendapatkan gambaran mengenai masalah yang akan diteliti, serta analisis penelitian yang dilakukan.

Penelitian Lapangan

Penelitian yang dilakukan dengan melihat dan mencatat data yang bersumber dari Laporan Keuangan LPD Adat Bangkang.

Dokumentasi

Pengumpulan data yang dilakukan dengan cara membuat salinan dari data yang sudah ada. Dalam menganalisis data, penulis 
menggunakan metode kuantitatif, yaitu dengan melakukan perhitungan yang relevan terhadap masalah yang diteliti. Adapun teknik analisis yang digunakan adalah $D u$ Pont dengan perhitungan $R O A$ dan $R O E$, dengan langkahlangkah yang diambil dari Bagan $D u$ Pont:

\section{Menentukan Asset Turnover (Perputaran Total Aktiva)}

Perputaran Total Aktiva adalah suatu rasio yang bertujuan untuk mengukur tingkat efisiensi aktiva perusahaan didalam menghasilkan pendapatan tertentu. Angka ini digunakan untuk mengukur keefektifan penggunaan aktiva. Assets Turnover yang baik adalah yang besar karena jika kecil berarti terdapat asset yang menganggur dan menyebabkan opportunity cost.

Aktiva Lancar

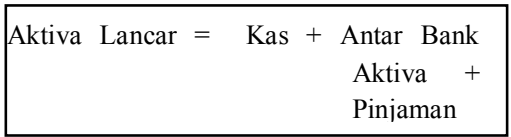

Total Aktiva

Total Aktiva $=$ Aktiva Lancar + Aktiva tetap

Perputaran Aktiva

Perputaran Aktiva $=\underline{\text { Pendapatan }}$

Total aktiva

Menentukan Rasio Laba Bersih/Profit Margin

Rasio laba bersih mengukur besarnya laba bersih yang dicapai dari sejumlah penjualan tertentu.

Total Biaya

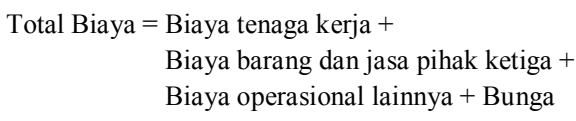

Laba Bersih

Laba Bersih $=$ Pendapatan - Total biaya
Profit Margin

$$
\text { Profit Margin }=\frac{\text { Laba bersih }}{\text { Pendapatan }}
$$

Menentukan Return On Asset (ROA) Du Pont

$R O A$ dapat mengukur tingkat untuk mengukur kemampuan manajemen dalam memperoleh profitabilitas Lembaga Perkreditan Desa Bangkang Baktiseraga. Standar rata-rata ROA menurut Peraturan Bank Indonesia adalah $1,5 \%$.

\section{Menilai Kinerja Keuangan Perusahaan}

Kriteria perusahaan yang baik

ROA (Du Pont) berada di atas rata-rata 1,5\% menunjukkan bahwa perputaran aktiva dan net profit margin sangat tinggi. Hal ini menunjukkan bahwa kinerja perusahaan dalam menghasilkan laba semakin baik.

Kriteria perusahaan yang kurang baik

ROA (Du Pont) berada dibawah rata-rata menunjukkan bahwa perputaran aktiva dan net profit margin sangat rendah. Hal ini menunjukkan bahwa kinerja perusahaan dalam menghasilkan laba kurang baik.

$R O A=$ Profit margin $\mathrm{x}$ Asset Turnover

Menentukan Return On Equity (ROE) diambil dari Bagan Du Pont:

Menentukan Equity Multiplier

Equity Multiplier $=\underline{\text { Total Aktiva }}$

Ekuitas

Menentukan Return On Equity

Return On Equity adalah rasio laba bersih terhadap ekuitas biasa dengan mengukur tingkat pengembalian atas investasi.

$R O E=R O A \times$ Equity multiplier

ROE bersifat menyeluruh karena mencakup tingkat efisiensi perusahaan dalam penggunaan 
aktivanya dan dapat mengukur tingkat keuntungan atas pendapatan yang dihasilkan oleh perusahaan tersebut. Semakin tinggi rasio ini semakin baik, artinya posisi pemilik perusaha semakin kuat, demikian pula sebaliknya. Standar rata-rata $R O E$ menurut Peraturan Bank Indonesia adalah 12\%.

Penelitian ini mengambil data yang diperoleh dalam bentuk sudah jadi yang dikumpulkan, diolah, yang diberikan oleh Lembaga Perkreditan Desa Bangkang Baktiseraga.

\section{HASIL DAN PEMBAHASAN}

Pada umumnya, suatu perusahaan bisa dianalisis secara tersendiri. Dapat melakukan analisis terhadap bisnisnya secara mendalam dan menghasilkan suatu kesimpulan. Walaupun begitu, perlu dibandingkan kinerjanya dengan standar rata-rata Bank Indonesia. Dengan begitu, akan mendapatkan pemahaman yang lebih lengkap mengenai bisnis suatu perusahaan. Tidak terbatas pada hal itu saja, analisis juga dapat dimanfaatkan kinerja suatu perusahaan dari waktu ke waktu.

Menganalisis kinerja keuangan dapat dilakukan dengan perhitungan rasio-rasio keuangan. Rasio keuangan dapat memberikan pemahaman yang lebih baik dan mudah dipahami untuk mengetahui kinerja perusahaan. Hasil perhitungan rasio ini dapat dibandingkan dengan suatu nilai standar rasio keuangan suatu perusahaan sejenis untuk mengetahui posisi perusahaan. Rasio keuangan merupakan alat yang penting untuk mengukur perkembangan suatu usaha.

Menganalisis kinerja keuangan perusahaan selain menggunakan perhitungan rasio keuangan dapat dilakukan dengan menggunakan analisis $D u$ Pont. Sistem $D u$ Pont adalah suatu perangkat analisis keuangan yang dikembangkan dari rasio-rasio keuangan.

Analisis laporan keuangan dilaksanakan baik dalam perusahaan yang bertujuan mencari laba maupun dalam organisasi-organisasi yang tidak mencari laba. Namun demikian alasan utama mengapa analisis laporan keuangan dilaksanakan dalam berbagai organisasi, karena semakin rumitnya variabel-variabel yang dihadapi para manajer walau didalam perusahaan kecil. Keadaan ini mengakibatkan para manajer semakin tergantung pada proses akuntansi dimana transaksi-transaksi perusahaan diubah menjadi data statistik dan diringkas serta dilaporkan dalam laporan keuangan.

Dalam masyarakat terdapat pula pihakpihak di luar pengelola perusahaan yang juga membutuhkan informasi keuangan salah satunya para kreditur yang harus mempertimbangkan kemampuan keuangan pemohon kredit, dapat pula untuk menilai prestasi kerja manajemen dan menilai penyertaan dalam Lembaga Perkreditan Desa Adat Bangkang. Laporan keuangan adalah hasil dari proses akuntansi yang disebut siklus akuntansi. Laporan keuangan menunjukkan posisi sumber daya yang dimiliki oleh Lembaga Perkreditan Desa Adat Bangkang dalam satu periode. Selain itu, laporan keuangan juga menunjukkan kinerja keuangan Lembaga Perkreditan Desa yang ditunjukkan kemampuan Lembaga Perkreditan Desa dalam menghasilkan pendapatan dengan sumber daya yang dimiliki oleh Lembaga Perkreditan Desa.

Analisis laporan keuangan seringkali juga memasukkan aktivitas untuk membuat berbagai macam transformasi atas laporan keuangan. Jika analisis hanya menganalisis akun yang ada dalam laporan keuangan, maka analis akan kesulitan menilai seberapa baik Lembaga Perkreditan Desa beroperasi. Teknik analisis yang digunakan adalah analisis rasio dan analisis persentase yang memungkinkan untuk mengidentifikasikan, mengkaji, dan merangkum hubungan-hubungan yang signifikan dari data keuangan Lembaga Perkreditan Desa.

Untuk mengevaluasi kinerja dan kondisi keuangan Lembaga Perkreditan Desa, analis keuangan dan pemakai laporan keuangan harus melakukan analisis terhadap kesehatan Lembaga Perkreditan Desa. Alat yang bisa digunakan adalah rasio keuangan. Dalam analisis rasio, ada dua jenis perbandingan yang digunakan yaitu perbandingan internal dan 
perbandingan eksternal. Perbandingan internal yaitu membandingkan rasio saat ini dengan rasio masa lalu dan rasio yang akan datang dari satu perusahaan. Jika rasio ini diurutkan dalam beberapa tahun atau periode, pemakai dapat melihat kecendrungan rasio keuangan, apakah mengalami penurunan atau peningkatan, yang menunjukkan kinerja atau kondisi keuangan Lembaga Perkreditan Desa. Sedangkan perbandingan eksternal adalah membandingkan rasio keuangan Lembaga Perkreditan Desa dengan standar rata-rata rasio Bank Indonesia. Perbandingan ini merupakan pemahaman yang mendalam tentang kondisi dan kinerja Lembaga Perkreditan Desa relatif dan membantu mengidentifikasi dari penyimpangan standar rata-rata.

Berdasarkan data yang dikumpulkan yang kemudian dianalisis menggunakan alat analisis keuangan dan didukung dengan teori-teori keuangan yang telah dikemukakan di atas maka penulis mengemukakan hasil dan pembahasan penelitian sebagai berikut:

\section{Analisis $\mathrm{Du}$ Pont}

Penilaian kinerja keuangan perusahaan akan menggunakan cara sistem $\mathrm{Du}$ Pont yaitu merupakan suatu sistem analisis yang menunjukkan hubungan antara Return On Asset (ROA), Assets Turnover (ATO), dan profit margin (PM). Besarnya $R O A$ akan berubah jika ada perubahan pada profit margin atau assets turnover, baik masing-masing atau keduaduanya. Dengan demikian dapat menggunakan salah satu atau keduanya dalam rangka meningkatkan ROA. Dengan memakai sistem Du Pont ini, dapat dilihat terdapat kenaikan maupun penurunan dari tiap-tiap laporan keuangan Lembaga Perkreditan Desa tersebut. Sifatnya yang menyeluruh sehingga dapat mengukur dan membandingkan efisiensi profitabilitas yang dihasilkan.

Analisis Du Pont tetap digunakan sebagai salah satu teknik untuk melakukan analisis keuangan Lembaga Perkreditan Desa Adat Bangkang. Salah satu keunggulan dari analisis ini adalah terletak pada laba dengan menggunakan Return On Asset dan Return On Equity sebagai alat ukurnya. Penggunaan analisis $\mathrm{Du}$ Pont memungkinkan manajemen melihat dengan lebih jelas faktor pemicu tingkat pengembalian ekuitas serta hubungan antara margin laba bersih, perputaran aktiva, dan rasio utang. Manajemen dipandu dalam menentukan efektivitas pengelolaan sumber daya perusahaan untuk memaksimumkan tingkat pengembalian investasi para pemilik.

Penggunaan analisis $D u$ Pont didalam menganalisis kinerja Lembaga Perkreditan Desa adalah untuk mengetahui komponenkomponen apa yang mempengaruhi nilai Return On Equity (ROE) perusahaan dan sekaligus menghitung nilai Return On Equity. Untuk menggunakan rumus Return On Equity, komponen-komponen laba bersih, pendapatan, total asset dan ekuitas harus diketahui terlebih dahulu. Nilai komponen tersebut dapat dicari dari laporan keuangan perusahaan. Sebelum mencari nilai $R O E$, harus mencari nilai beberapa rasio.

Menentukan Asset Turnover (Perputaran Total Aktiva)

Digunakan untuk mengukur penggunaan semua aktiva Lembaga Perkreditan Desa. Kemudian juga mengukur berapa jumlah pendapatan yang diperoleh dari tiap rupiah aktiva dan biasanya rasio ini dinyatakan dengan desimal. Total asset turnover merupakan rasio yang menggambarkan perputaran aktiva diukur dari pendapatan. Jadi semakin besar rasio ini semakin baik, yang berarti bahwa aktiva dapat lebih cepat berputar, meraih laba, dan menunjukkan semakin efisien penggunaan keseluruhan aktiva dalam menghasilkan pendapatan. Asset turnover penting bagi manajemen Lembaga Perkreditan Desa Bangkang, karena akan menunjukkan efisien tidaknya penggunaan seluruh aktiva dalam Lembaga Perkreditan Desa Adat Bangkang. Asset Turnover langkah pertama adalah menentukan nilai aktiva lancar. 
Versi Online: http://journal.ubm.ac.id/

Hasil Penelitian

Aktiva Lancar

Aktiva adalah sumber daya yang dikuasai oleh perusahaan sebagai akibat dari peristiwa masa lalu, dan dari manfaat ekonomis di masa depan diharapkan akan diperoleh perusahaan. Aktiva lancar adalah jenis asset yang dapat digunakan dalam jangka waktu dekat, biasanya maksimal satu tahun. Aktiva lancar adalah uang kas dan aktiva-aktiva lain atau sumber-sumber yang diharapkan akan direalisasikan menjadi uang kas atau dikonsumsi, atau dijual selama siklus usaha perusahaan yang normal atau dalam waktu satu tahun.

Jumlah Aktiva Lancar dalam Lembaga Perkreditan Desa Adat Bangkang dari tahun 2014 sampai tahun 2016 mengalami penurunan, pada tahun 2014 adalah Rp.186.167.000, dan pada tahun 2015 mengalami penurunan yaitu Rp.186.373.000, begitu juga tahun 2016 semakin menurun menjadi Rp.181.272.000.

Total Aktiva

Total Aktiva adalah hasil penjumlahan dari aktiva lancar dengan Aktiva Tetap. Aktiva Tetap adalah aktiva yang dimiliki perusahaan yang diperoleh dalam bentuk siap pakai atau dibangun terlebih dahulu, sifatnya permanen dan digunakan dalam kegiatan normal perusahaan untuk jangka panjang serta nilai cukup material. Aktiva Tetap pada Lembaga Perkreditan Desa Adat Bangkang Baktiseraga terdiri dari Harga Perolehan dan Rupa-Rupa Aktiva.

Total Aktiva dalam Lembaga Perkreditan Desa Bangkang adalah pada tahun 2014 Rp.198.266.000, dan di tahun 2015 mengalami peningkatan yaitu Rp.223.384.000, sedangkan tahun 2016 lebih rendah dari tahun 2015 yaitu Rp.211.798.000.

\section{Asset Turnover (Perputaran Total Aktiva)}

Dilihat dari perhitungan pada analisis $D u$ Pont, Asset Turnover yang dihasilkan dari tahun 2014 adalah 0,32 sampai tahun 2015 adalah 0,19 mengalami penurunan, dan tahun
Business Management Journal

Vol.14 (No. 2 ) : 75 - 153. Th. 2018

ISSN: 1907-0896

E-ISSN: 2598-6775

2016 lebih baik dari pada tahun 2015 yaitu 0,22 , yang berarti bahwa aktiva lambat perputarannya, meraih laba, dan menunjukkan kurang efisien penggunaan keseluruhan aktiva dalam menghasilkan pendapatan. Total aktiva berhubungan terhadap Asset Turnover. Semakin besar Total Aktiva semakin besar Asset Turnover yang dilihat pada hasil perhitungan di atas.

Menentukan Rasio Laba Bersih/Profit Margin

Profit margin adalah rasio yang menunjukkan kemampuan perusahaan menghasilkan sejumlah laba dari setiap tingkat pendapatan. Profitabilitas dinyatakan tinggi apabila mampu menghasilkan profit margin yang tinggi. Sejauh mana kemampuan Lembaga Perkreditan Desa Bangkang menekan biaya-biaya yang ada. Profit margin yang tinggi menandakan kemampuan Lembaga Perkreditan Desa menghasilkan laba yang tinggi, disebabkan tingkat pendapatan lebih tinggi dari biaya operasional, sedangkan profit margin yang rendah menunjukkan ketidakefisienan manajemen. Langkah-langkah menghitung profit margin:

Total Biaya

Total Biaya adalah seluruh biaya yang dikorbankan yang merupakan totalitas dari seluruh biaya yang ada Lembaga Perkreditan Desa Bangkang Baktiseraga.

Pada tahun 2014 Total Biaya yang dihasilkan oleh Lembaga Perkreditan Desa Adat Bangkang adalah Rp.51.251.000, tahun 2015 adalah Rp.33.339.000, dan pada tahun 2016 adalah Rp.37.816.000.

Laba Bersih

Laba bersih adalah selisih lebih semua pendapatan dan keuntungan terhadap semua biaya dan kerugian yang merupakan kenaikan bersih atas modal.

Lembaga Perkreditan Desa Bangkang pada tahun 2014 menghasilkan laba bersih sebesar Rp.12.903.000, tahun 2015 menurun menjadi 
Rp.8.324.000, sedangkan tahun 2016 menunjukkan nilai yang lebih baik yaitu sebesar Rp.9.277.000.

\section{Profit Margin}

Dilihat dari hasil perhitungan pada gambar analisis $D u$ Pont, Profit Margin yang dihasilkan dari tahun 2014 sampai tahun 2016 mengalami penurunan, yaitu tahun 2014 adalah 0,201, di tahun 2015 sebesar 0,200, dan ditahun 2016 sebesar 0,197, ini menandakan kurang efisien manajemen Lembaga Perkreditan Desa Adat Bangkang Baktiseraga dalam menekan biaya-biaya yang diperlukan dalam Lembaga Perkreditan Desa Adat Bangkang Baktiseraga.

Menentukan Return On Asset

Return On Asset adalah salah satu bentuk dari rasio profitabilitas untuk mengukur kemampuan perusahaan dalam menghasilkan laba dengan menggunakan total aktiva yang ada, yang berarti juga suatu ukuran untuk menilai seberapa besar tingkat pengembalian dari asset yang dimiliki Lembaga Perkreditan Desa Adat Bangkang Baktiseraga.

Return On Asset yang positif menunjukkan bahwa dari total aktiva yang dipergunakan untuk operasi Lembaga Perkreditan Desa mampu memberikan laba bagi Lembaga Perkreditan Desa.

Jika dilihat dari perhitungan di atas Return On Asset pada Lembaga Perkreditan Desa Adat Bangkang Baktiseraga dari tahun 2014 ke tahun 2015 menurun, yaitu ditahun 2014 sebesar 6,5\%, tahun 2015 sebesar 3,7\%, sedangkan pada tahun 2016 lebih baik dari pada tahun 2015 yaitu 4,4\%. Walaupun Return On Asset pada Lembaga Perkreditan Desa Adat Bangkang Baktiseraga mengalami penurunan, tetapi Kinerja Laporan Keuangan Lembaga Perkreditan Desa Adat bangkang Baktiseraga dinyatakan sehat, karena berada di atas standar rata-rata Return On Asset Bank Indonesia yaitu $1,5 \%$. Hal ini menunjukkan bahwa kinerja perusahaan dalam menghasilkan laba berarti baik.
Menghitung Return On Equity

Return On Equity adalah perbandingan antara laba bersih dengan modalnya. Rasio ini digunakan untuk mengukur kinerja manajemen Lembaga Perkreditan Desa Adat Bangkang dalam mengelola modal yang tersedia untuk menghasilkan laba bersih. Semakin besar Return On Equity, semakin besar tingkat keuntungan yang dicapai sehingga kemungkinan Lembaga Perkreditan Desa bermasalah semakin kecil. Kenaikan dalam rasio ini berarti terjadi kenaikan laba bersih. Langkah-langkah menghitung Return On Equity:

\section{Menghitung Equity Multiplier}

Rasio ini menunjukkan kemampuan Lembaga Perkreditan Desa Adat Bangkang Baktiseraga dalam mendayagunakan ekuitas pemegang saham. Rasio ini juga bisa diartikan sebagai beberapa porsi dari aktiva Lembaga Perkreditan Desa Adat Bangkang Baktiseraga yang dibiayai oleh pemegang saham. Semakin kecil rasio ini, berarti porsi pemegang saham akan semakin besar, sehingga kinerjanya akan semakin baik, karena persentase untuk pembayaran bunga semakin kecil. Rasio ini adalah total aktiva dibagi ekuitas.

Equity Multiplier dapat diketahui sampai tingkat mana pemegang saham menanggung resiko terhadap total aktiva LPD. Rasio ini tidak seharusnya meningkat dari waktu kewaktu, karena hal tersebut menandakan semakin banyak hutang yang digunakan untuk mendanai LPD. Hutang menimbulkan kewajiban untuk membayar angsuran pinjaman dan bunga pinjaman, dan jika LPD tidak bisa melaksanakan kewajibannya maka LPD terpaksa mengalami kebangkrutan. Sehingga tingginya rasio ini menunjukkan manajemen struktur modal yang buruk.

Pada tahun 2014 Equity Multiplier pada Lembaga Perkreditan Desa Adat Bangkang Baktiseraga menunjukkan angka 7,70 tahun 2015 menunjukkan angka 9,49, dan ditahun 2016 menunjukkan 8,10. Equity Multiplier 
Versi Online: http://journal.ubm.ac.id/ Hasil Penelitian

pada Lembaga Perkreditan Desa Adat Bangkang sangat tinggi berarti manajemen struktur modal yang tidak baik.

\section{Menghitung Return On Equity}

Return On Equity adalah suatu pengukuran dari penghasilan atau income yang tersedia atas modal yang mereka investasikan di dalam LPD. Return On Equity digunakan untuk mengukur laba bersih setelah pajak dengan modal sendiri. Sekaligus mengukur tingkat efisiensi penggunaan modal sendiri. Semakin tinggi rasio ini semakin baik karena posisi Lembaga Perkreditan Desa semakin kuat.

Return On Equity Lembaga Perkreditan Desa Adat Bangkang Baktiseraga berfluktuasi. Tahun 2014 sebesar 50,08\%, tahun 2015 menurun menjadi $35,37 \%$, sedangkan tahun 2016 lebih tinggi dari tahun 2015 yaitu 35,47\%. Kalau dilihat dari perkembangan dari tahun ke tahun kinerjanya menurun berarti tidak bagus, tetapi dilihat dari standar rata-rata Bank Indonesia Return On Equity dinyatakan sehat menunjukkan angka $12 \%$, ini berarti kinerja Lembaga Perkreditan Desa Adat Bangkang Baktiseraga dapat dinyatakan sehat, karena berada jauh di atas rata-rata industri, walaupun dari tahun 2014 sampai 2016 mengalami penurunan.

Hasil Perhitungan Analisis Du Pont Lembaga Perkreditan Desa Adat Bangkang Baktiseraga.

Setelah kita melihat analisis Sistem $D u$ Pont dari Lembaga Perkreditan Desa Adat Bangkang Baktiseraga, maka berikut di bawah ini adalah hasil analisis dari laporan keuangan selama 3 tahun. Dengan cara ini dapat dilihat adanya kenaikan atau penurunan dari tiap-tiap pos pada laporan keuangan tersebut. Berikut merupakan rekapitulasi perkembangan Return On Asset, Profit Margin dan Asset Turnover, Equity Multiplier dan Return On Equity pada Lembaga Perkreditan Desa Adat Bangkang Baktiseraga periode tahun 2014-2016 yang sudah dianalisis dengan menggunakan sistem Du Pont.
Business Management Journal

Vol.14 (No. 2 ) : 75 - 153. Th. 2018

ISSN: 1907-0896

E-ISSN: 2598-6775

Tabel 2. Rekapitulasi Perkembangan ROA, $P M, A T O, E M$, dan ROE pada Lembaga Perkreditan Desa Adat Bangkang Baktiseraga Periode Tahun 2010-2012.

\begin{tabular}{|l|r|r|r|r|l|}
\hline TAHUN & \multicolumn{1}{|l|}{ TTO } & $\boldsymbol{P M}$ & $\boldsymbol{R O A}$ & $\boldsymbol{R}$ & $\boldsymbol{R} \boldsymbol{\text { RE }}$ \\
\hline 2010 & $0,32 \mathrm{kali}$ & $20,1 \%$ & $6,5 \%$ & 7,70 & $50,08 \%$ \\
\hline 2011 & $0,19 \mathrm{kali}$ & $20 \%$ & $3,7 \%$ & 9,49 & $35,37 \%$ \\
\hline 2012 & $0,22 \mathrm{kali}$ & $19,7 \%$ & $4,4 \%$ & 8,10 & $35,47 \%$ \\
\hline
\end{tabular}

Sumber: Data keuangan LPD Adat Bangkang yang diolah

Tabel 2 menunjukkan perbandingan $R O A, P M$, $A T O, E M$ dan $R O E$ dari Lembaga Perkreditan Desa Adat Bangkang Baktiseraga selama tahun 2014-2016. Jika dilihat dari tingkat rata-rata Return On Asset selama tahun 2014-2016 maka tahun 2014 menunjukkan persentase 6,5\%, kemudian diikuti pada tahun 2015 dengan presentase sebesar $3,7 \%$, selanjutnya menyusul tahun 2016 dengan presentase sebesar 4,4\%. Jika dilihat dari rata-rata Profit Margin (PM) maka susunannya tahun 2014 yaitu sebesar 20,1\%, kemudian diikuti tahun 2015 dengan presentase sebesar $20 \%$, selanjutnya menyusul tahun 2016 dengan presentase sebesar 19,7\%. Namun jika dilihat dari rata-rata Assets Turnover (ATO) tahun 2014 sampai tahun 2016 mengalami penurunan yaitu sebesar 0,32 kali, kemudian sebesar 0,19 kali, selanjutnya meningkat yaitu sebesar 0,22 kali. Untuk Equity Multiplier tahun 2014 sebesar 7,70, tahun 2015 sebesar 9,49, sedangkan tahun 2016 menunjukkan nilai sebesar 8,10. Untuk Return On Equity menurun pada tahun 2014 sebesar $50,08 \%$ sedangkan tahun 2015 sebesar 35,37 $\%$, dan tahun 2016 sebesar 35,47\%. Lembaga Perkreditan Desa Adat Bangkang Baktiseraga memiliki kinerja keuangan yang sehat jika dilihat dari perhitungan Return On Asset dan Return On Equity, walaupun terjadi penurunan dari tahun 2014 sampai tahun 2016.

Berdasarkan hasil perhitungan di atas, konsep hipotesis yang menyatakan:

1. Jika $R O A$ semakin menunjukkan nilai yang besar maka Lembaga Perkreditan Desa Adat Bangkang Baktiseraga dinyatakan sehat telah terbukti, 
walaupun terjadinya penurunan Return On Asset dari tahun 2014 sampai tahun 2016, nilai Return On Asset lebih besar dari standar rata-rata Bank Indonesia.

2. Begitu juga dengan hipotesis yang menyatakan jika $R O E$ tinggi maka Lembaga Perkreditan Desa Adat BangkangBaktiseraga semakin bagus dan dinyatakan sehat, hal ini sama dengan Return On Asset, walaupun mengalami penurunan tetapi nilai Return On Equity diatas standar ratarata Bank Indonesia.

\section{SIMPULAN DAN SARAN}

Berdasarkan hasil penelitian pada Lembaga Perkreditan Desa Adat Bangkang Baktiseraga dapat disimpulkan sebagai berikut: Jika dilihat dari Profit Margin, dan Asset Turnover pada Lembaga Perkreditan Desa Adat Bangkang mengalami penurunan, rata-rata Profit Margin (PM) maka susunannya tahun 2014 yaitu sebesar 20,1\%, kemudian diikuti tahun 2015 dengan presentase sebesar 20\%, selanjutnya menyusul tahun 2016 dengan presentase sebesar 19,7\%. Namun jika dilihat dari rata-rata Assets Turnover (ATO) tahun 2014 sampai tahun 2016 mengalami penurunan yaitu sebesar 0,32 kali, kemudian sebesar 0,19 kali, selanjutnya meningkat yaitu sebesar 0,22 kali. Untuk Equity Multiplier meningkat dari tahun ke tahun, tahun 2014 sebesar 7,70, tahun 2015 sebesar 9,49, sedangkan tahun 2016 menunjukkan nilai sebesar 8,10.

Nilai $R O E$ perusahaan dari tahun 2014 hingga tahun 2016 bernilai positif, di atas standar ratarata Bank Indonesia, walaupun terjadi penurunan terus-menerus dari tahun ke tahun, tingkat rata-rata pada tahun 2014 sebesar $50,08 \%$ sedangkan tahun 2015 sebesar 35,37 $\%$, dan tahun 2016 sebesar 35,47\%. Hasil penelitian ini menggambarkan bahwa perusahaan telah berhasil memperoleh keuntungan, walaupun belum dapat meningkatkan keuntungan sepanjang tahun 2014-2016 . Nilai $R O A$ yang positif, di atas rata-rata standar Bank Indonesia ini menunjukkan bahwa perusahaan berhasil mendatangkan keuntungan dengan penggunaan asset perusahaan. Return On Asset selama tahun 2014-2016 maka tahun 2014 menunjukkan persentase $6,5 \%$, kemudian diikuti pada tahun 2015 dengan presentase sebesar 3,7\%, selanjutnya menyusul tahun 2016 dengan presentase sebesar 4,4\%. Lembaga Perkreditan Desa Adat Bangkang Baktiseraga memiliki kinerja keuangan yang sehat jika dilihat dari perhitungan analisis $\mathrm{Du}$ Pont.

Saran yang dapat diajukan penulis sebagai berikut:

Bagi Lembaga Perkreditan Desa Adat Bangkang Baktiseraga.

Untuk meningkatkan Retun On Asset dan Return On Equity dengan cara meningkatkan Profit Margin dan menurunkan Equity Multiplier, menggunakan modal dan asset untuk mendapatkan keuntungan, dengan cara menarik minat nasabah untuk menabung di Lembaga Perkreditan Desa Adat Bangkang Baktiseraga juga dengan meminjam kredit pada LPD Adat Bangkang. Contohnya dengan cara memberikan undian berhadiah agar nasabah tertarik untuk menabung di Lembaga Perkreditan Desa Adat Bangkang Baktiseraga.

Bagi Peneliti Berikutnya.

Analisis keuangan yang digunakan penulis adalah sistem $D u$ Pont, masih banyak jenis alat analisis keuangan yang dapat dipergunakan untuk menganalisis kinerja keuangan suatu Lembaga Perkreditan Desa. Oleh karena itu bagi peneliti berikutnya dapat melakukan penelitian menggunakan metode lain atau dapat juga membandingkan Lembaga Perkreditan Desa ini dengan Lembaga Perkreditan Desa lain dengan menggunakan analisis keuangan yang sama.

\section{DAFTAR PUSTAKA}

Abdulah. 2001. Dasar-Dasar manajemen Keuangan. Jawa Timur: Universitas Muhamadiyah Malang. 
Versi Online: http://journal.ubm.ac.id/

Hasil Penelitian

Anonymous. Laporan Keuangan LPD Bangkang Baktiseraga tahun 2014-2016.

Anonymous. Peraturan Daerah Provinsi Bali Nomor 4 Tahun 2012 Tentang Lembaga Perkreditan Desa.

Bodie, Kane \& Marcus. 2002. Investment, 6th edition, International Edition, MCGraw Hill International.

Gulo. 2002. Metode Penelitian. Jakarta: PT.Grasindo.

Harahap. 2002. Akuntansi Aktiva Tetap. Bumi Aksara: Jakarta.

Harahap. 2009. Analisis Kritis Atas Laporan Keuangan. Jakarta: Raja Grafindo Persada.

Harahap. 2011. Analisis Kritis atas Laporan Keuangan.Jakarta: PT. Raja Grafindo Persada.

Husnan \& Pudjiastuti. 2004. Dasar-dasar Manajemen Keuangan, Edisi Ke Empat, Jakarta.

Ikatan Akuntansi Indonesia. 2004. Standar Akuntansi Keuangan, Jilid Pertama, Salemba.

Ikatan Akuntansi Indonesia. 2009. Standar Akuntansi Keuangan. PT. Salemba Empat : Jakarta

Kasmir. 2011. Dasar-Dasar Perbankan. Jakarta: PT. Raja Grafindo Persada.

Keown. 2004. Financial Management, Tenth Edition. Prentice Hall. United.

Mahsun. 2006. Pengukuran Kinerja Sektor Publik, Edisi Pertama.
Business Management Journal

Vol.14 (No. 2 ) : 75 - 153. Th. 2018

ISSN: 1907-0896

E-ISSN: 2598-6775

Margono. 2004. Metodologi Penelitian Pendidikan. Jakarta: Rineka Cipta.

Munawir. 2010. Analisa Laporan Keuangan, Edisi keempat. Yogyakarta : Liberty

Rahardjo. 2001. Akuntansi dan Keuangan Untuk Manajer Non Keuangan, Edisi 1. Yogyakarta: Andi.

Ridwan \& Inge. 2003. Manajemen Keuangan 2, Edisi Keempat. Yogyakarta: Literata Lintas Media.

Sawir. 2001. Kinerja Keuangan dan Perencanaan Keuangan Perusahaan, Edisi Pertama, Jakarta : PT. Gramedia Pustaka Utama, anggota IKAPI.

Sawir. 2003. Analisis Kinerja Keuangan dan Perencanaan Keuangan Perusahaan. Jakarta: PT. Gramedia Pustaka Utama.

Soediyono. 2001. Ekonomi Makro Pengantar Teori Makro Ekonomi. Jakarta: PT. Raja Grafindo Persada.

Sutrisno. 2001.

Manajemen

Keuangan.Ekonesia: Yogyakarta.

2001. Manajemen Keuangan Teori. Konsep dan Aplikasi. Yogyakarta: Ekonisia.

Syamsudin. 2000. Manajemen Keuangan Perusahaan. Jakarta : PT Raja Grafindo Persada.

Warsono. 2003. Manajemen Keuangan. Yogyakarta: Universitas Gajah Mada. 